Tsvetina Dobrovolska1 ${ }^{1}$ Uroš Lačnjevac ${ }^{2}$, Nikola Tasić ${ }^{2}$ Borka Jović2 ${ }^{2}$ Vladimir Jović ${ }^{2}$, Nevenka Elezović ${ }^{2 \star}$

${ }^{1}$ Bulgarian Academy of Sciences, Institute of Physical Chemistry, Sofia, Bulgaria, ${ }^{2}$ University of Belgrade, Institute for Multidisciplinary Research, Belgrade, Serbia
Scientific paper

ISSN 0351-9465, E-ISSN 2466-2585

UDC:620.193.91

doi: $10.5937 /$ ZasMat1802237D

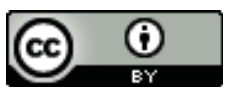

Zastita Materijala 59 (2)

237 - 242 (2018)

\title{
Spatio-temporal structures of electrodeposited indium based alloys
}

\begin{abstract}
Ag-In, Pd-In and Co-In alloy coatings were electrodeposited under galvanostatic conditions from different solutions. The appearance and the composition of coatings were investigated by scanning electron microscopy (SEM) and energy-dispersive $X$-ray spectroscopy (EDS).

The appearance of spatio-temporal structures on the surface od electrodeposited alloy layers is characteristic for all three indium containing alloys. Well-distinguished spirals were detected only at the surfaces of Ag-In and Co-In alloys, while for Pd-In alloy spatio-temporal structures are characterized with the valleys of different shapes surrounded by hills.

In the case of Ag-In and Pd-In alloy coatings the cross-section does not show the presence of alloy layers with different composition, due to the fact that spatio-temporal structures are of large dimensions and cannot be seen on the high magnification images of the cross-sections.

EDS line scan of the cross-section of Co-In alloy layers indicates the presence of layers with different compositions at high magnification, confirming that spatio-temporal structures are placed not only on the surface, but also in the bulk of the alloy coating.
\end{abstract}

Keywords: spatio-temporal structures, spirals, electrodeposited In alloys, cross-section.

\section{INTRODUCTION}

Since the properties of heterogeneous alloy coatings are a mixture of the properties of the different phases present in the alloy coatings, pattern and spatio-temporal structures formation on the surface of the coatings, known as selforganization phenomena during their electrodeposition, is a consequence of the distribution of different phases in the coating, as well as on its surface [1,2].

The first spatio-temporal structure was observed in 1938 by Raub and Schall [3] in the system Ag-In, explained as transition from chaotically distributed phases of the alloy into welldefined periodic spiral structures caused by the fact that the In-rich phase sometimes forms welldefined crystallization spirals on the surface of the Ag-rich alloy coating. More than 50 years later similar structure formation was observed in several alloy systems $[1,2]$.

Corresponding author: Nevenka Elezović

E-mail address: nelezovic@tmf.bg.ac.rs

Paper received: 05. 03.2018.

Paper accepted: 24. 03. 2018.

Paper is available on the website: www.idk.org.rs/journal
This phenomenon is characteristic for In containing alloys [2]. The spatio-temporal structures in Ag-In alloys electrodeposited from cyanide electrolytes were investigated by Krastev et al. [4]. Some other aspects, composition and structure of the same alloy coatings electrodeposited from cyanide electrolytes were investigated by Dobrovolska et al. [5].

As for electrochemical deposition and characterization of Co-In alloys, Sadana et al. [6] studied the effect of current density on the electrodeposit composition and current efficiency. It was found that, depending on current density, composition changes from 2.0 to 90.6 wt. \% Co, while addition of ammonium citrate improved current efficiency [6]. Some aspects of electrodeposition of Sb-In, Sb-Co and In-Co alloys from basic citrate electrolyte were investigated by Nineva et al. [7]. The observed spatio-temporal structures onto the surface of Sb-Co and In-Co alloys and a large variety of patterns confirmed the existence of self-organization phenomena during the electrodeposition of these alloys [7].

In this research our attention is focused on some peculiarities of the electroplated layers of three indium containing alloys, $\mathrm{Ag}-\mathrm{In}, \mathrm{Pd}-\mathrm{In}$ and 
Co-In, electrodeposited from the aqueous solutions at the conditions of the formation of spatio-temporal structures as waves, targets and spirals onto their surfaces, which could be observed even by naked eyes $[1,2]$. In these electrodeposited alloys spatiotemporal structures exist at the different scales, and only different magnification and different techniques could elucidate the phenomenon of scaling in the case of pattern formation. Patterns and spatio-temporal structures were mainly detected by optical microscopy onto alloy surfaces. In this work an attempt was made to detect these phenomena using SEM and EDS, not only on the alloy surfaces, but also along the depth of these alloy coatings (Ag-In, Pd-In and Co-In), analysing their cross-sections.

\section{EXPERIMENTAL}

All solutions were prepared using p.a. chemicals and distilled water. Different solutions and different $\mathrm{pH}$ values were used for the electrodeposition of these three alloys: for the AgIn alloys cyanide electrolyte with $\mathrm{pH} 8$ was used; for the Pd-In alloys ammoniacal alkaline electrolyte of $\mathrm{pH} 10$ was used; for the Co-In alloys di ammonium hydrogen citrate with $\mathrm{pH} 3.1$ was used. The compositions of the plating baths were the following: Ag-In coatings, $20 \mathrm{~g} \mathrm{dm}^{-3} \mathrm{D}+$ Glucose, 45 $\mathrm{g} \mathrm{dm}^{-3} \mathrm{KCN}, 3 \mathrm{~g} \mathrm{dm}^{-3} \mathrm{Ag}\left(\right.$ as $\mathrm{KAg}(\mathrm{CN})_{2}$ ) and $11 \mathrm{~g}$ $\mathrm{dm}^{-3}$ In (as $\mathrm{InCl}_{3}$ ); Pd-In coatings, $10 \mathrm{~g} \mathrm{dm}^{-3} \mathrm{NH}_{4} \mathrm{Cl}$, $10 \mathrm{~g} \mathrm{dm}^{-3}\left(\mathrm{NH}_{4}\right)_{2} \mathrm{SO}_{4}, 3 \mathrm{~g} \mathrm{dm}^{-3} \mathrm{Pd}$ (as Palluna 460), $9 \mathrm{~g} \mathrm{dm}^{-3}$ In (as InCl 3 ); Co-In coatings, $20 \mathrm{~g} \mathrm{dm}^{-3} \mathrm{di}-$ ammonium hydrogen citrate, $30 \mathrm{~g} \mathrm{dm}^{-3}$ Co (as $\mathrm{CoSO}_{4} \cdot 7 \mathrm{H}_{2} \mathrm{O}$ ), $5 \mathrm{~g} \mathrm{dm}^{-3}$ In (as $\mathrm{InCl}_{3}$ ). More details about electrodeposition parameters were described in the figure captions of this paper.

The coatings were electrodeposited under galvanostatic conditions at room temperature onto copper substrates $\left(4 \mathrm{~cm}^{2}\right)$ with platinized titanium anodes $\left(2 \times 10 \mathrm{~cm}^{2}\right)$. All samples were electrodeposited at the same charge, $Q=216 \mathrm{C}$.

The surface morphology and the composition of the coatings, as well as their cross-sections, were studied by SEM, Tescan VEGA TS 5130 MM equipped with an energy-dispersive X-ray spectroscopy detector INCAPentaFET-x3 (Oxford Instruments) for chemical composition analysis EDS.

\section{RESULTS AND DISCUSSION}

\subsection{Silver-indium alloys}

The electrodeposition of the Ag-In alloy is of regular type - after reaching the diffusion limiting current density of silver (which is metal with the more positive potential of electrodeposition) the indium starts to co-electrodeposit [8].

Fig. 1 shows optical microscopy image of the surface of Ag-In alloy coating electrodeposited at $j$ $=-0.3 \mathrm{~A} \mathrm{dm}^{-2}$. The dimension of electrode is $1 \times 1$ $\mathrm{cm}$. The coating is covered by spatio-temporal structures, spirals and targets (marked with arrows), characteristics of this alloy, formed by the indium richer phase (black colour) onto the silvermatt $\alpha$ - phase of silver. The distance between large spirals varies from $0.25-0.35 \mathrm{~mm}$.

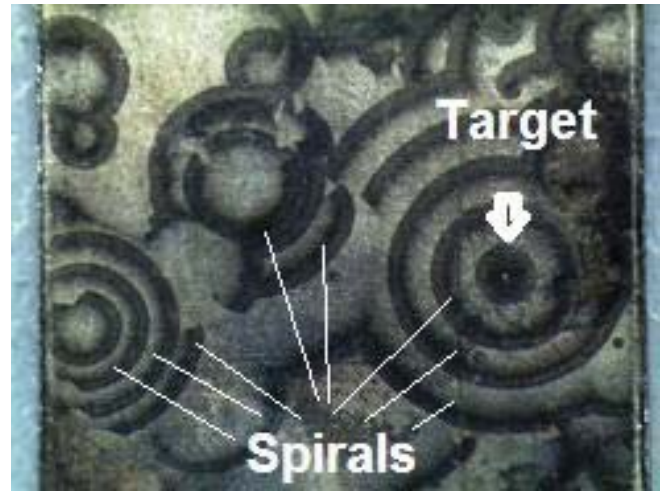

Figure 1. Optical microscopy image of the Ag-In coating, electrodeposited at $j=-0.3 \mathrm{~A} \mathrm{dm}^{-2}$ from the electrolyte containing $20 \mathrm{~g} \mathrm{dm}^{-3} \mathrm{D}+$ Glucose, 45 $\mathrm{g} \mathrm{dm}^{-3} \mathrm{KCN}, 3 \mathrm{~g} \mathrm{dm}^{-3} \mathrm{Ag}$ (as $\mathrm{KAg}(\mathrm{CN})_{2}$ ) and $11 \mathrm{~g}$ $d^{-3}$ In (as InCl $\mathrm{I}_{3}$ ). Electrodeposition time - $60 \mathrm{~min}$

Slika 1. Optička mikroskopska slika površine Ag-In prevlake elektrohemijski istaložene pri gustini struje

$j=-0.3 \mathrm{~A} \mathrm{dm}^{2}$. Sastav elektrolita: $20 \mathrm{~g} \mathrm{dm}^{-3}$

D+Glukoze, $45 \mathrm{~g} \mathrm{dm}^{-3} \mathrm{KCN}, 3 \mathrm{~g} \mathrm{dm}^{-3} \mathrm{Ag}$ (kao

$\left.\mathrm{KAg}(\mathrm{CN})_{2}\right)$ and $11 \mathrm{~g} \mathrm{dm}^{-3}$ In $\left(\mathrm{kaO} \mathrm{InCl}_{3}\right)$. Vreme taloženja - $60 \mathrm{~min}$

At higher magnifications these well-defined spirals cannot be seen, but certain irregularities, obtained by SEM, do exist at the Ag-In surface, as shown in Fig. 2(a). Different morphologies, depending on the amount of In, can be detected at high resolution, as shown in Fig. 2(b,c). Although the amount of In in the alloy differs for only $1 \mathrm{wt} . \%$ at different positions of sample shown in (a), different morphologies were obtained. A cauliflower type deposit with the nucleation exclusion zones characterize the surface of Ag-In alloy with $13 \mathrm{wt} \%$ In (b), while the endings of the alloy with 12 wt.\% In are rounded with small crystals on top of them (c). It was shown in our previous studies of this system [8] that electrodeposited Ag-In alloy contains Ag, $\mathrm{Ag}_{3} \mathrm{In}, \mathrm{Ag}_{9} \mathrm{In}_{4}$ and $\mathrm{Agln} \mathrm{n}_{2}$ phases. It appears that, according to the results of the EDS analysis, observed morphologies correspond to the phases of similar, or even identical, compositions. 

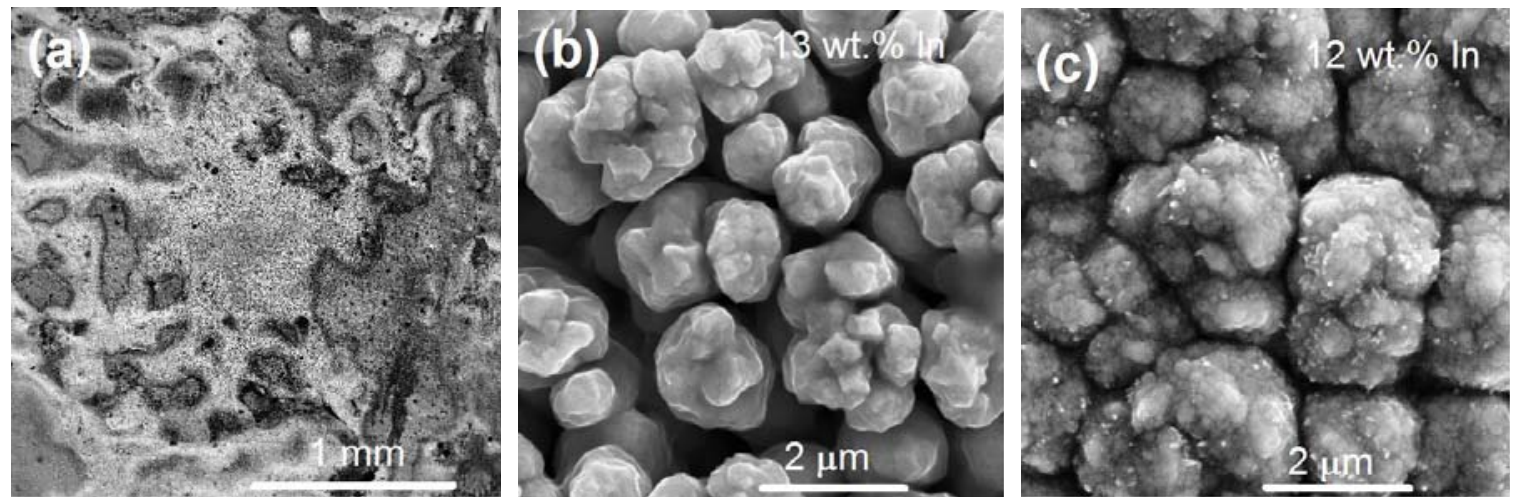

Figure 2(a)-(c). SEM images of certain surface areas from Fig. 1 at different magnifications

Slika 2(a)-(c). Skenirajuća elektronska mikroskopija određenih delova površine sa Slike 1, snimljene pri različitim uvećanjima

A cross-section of the Ag-In coating, presented in Fig. 3, confirms that the coating is thin (about 1.5 $\mu \mathrm{m})$. Taking into account that no different colors could be detected on the cross-section and that the composition of the Ag-In alloy is practically constant over the cross-section, containing only $\mathrm{Ag}$ (silver-matt $\alpha$ - phase), it seems that the part of the surface with the spirals has not been detected with the SEM-EDS analysis. Such result could be expected since the distance between spirals is very high $(0.25-0.35 \mathrm{~mm}$, Fig. 1) and the part of the surface (and the cross-section) with the spirals cannot be detected using SEM-EDS analysis. At the same time it could be concluded that spirals and targets could be seen at the surface only by using optical microscopy, i.e. at low resolutions.

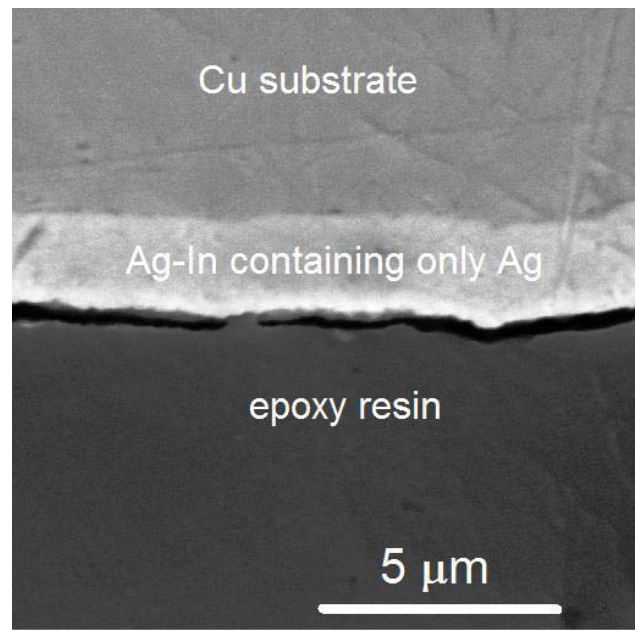

Figure 3. Cross-section of the Ag-In alloy coating

Slika 3. Poprečni presek prevlake Ag-In

\subsection{Palladium-indium alloys}

Pd-In alloys were electrodeposited from ammonia-containing electrolytes, similar to the deposition of gold-indium [9]. Spatio-temporal structures were observed onto the surface of the $\mathrm{Pd}$-In alloy layer electrodeposited at low current density (- $0.3 \mathrm{~A} \mathrm{dm}^{-2}$ ), Fig. 4 . In this case spatiotemporal structures are expressed mainly as linearly distributed waves.

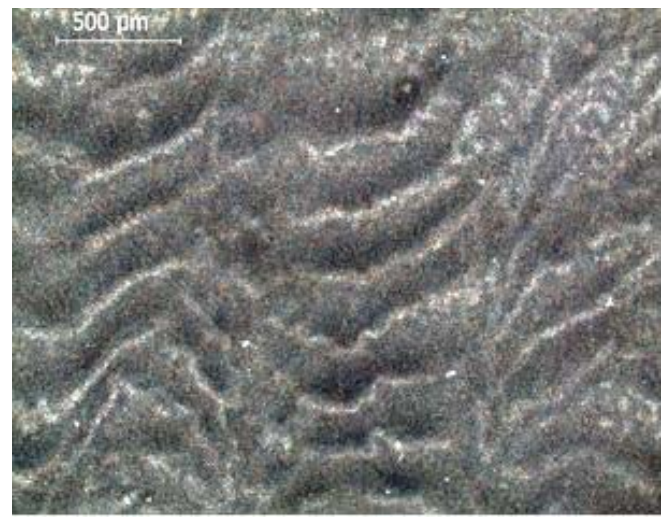

Figure 4. Optical microscopy image of $P d-I n$ coating electrodeposited at $j=-0.3 \mathrm{~A} \mathrm{dm}^{-2}$ from the electrolyte containing $10 \mathrm{~g} \mathrm{dm}^{-3} \mathrm{NH}_{4} \mathrm{Cl}, 10 \mathrm{~g} \mathrm{dm}^{-3}$ $\left(\mathrm{NH}_{4}\right)_{2} \mathrm{SO}_{4}, 3 \mathrm{~g} \mathrm{dm}^{-3} \mathrm{Pd}$ (as Palluna 460), $9 \mathrm{~g} \mathrm{dm}^{-3}$ In (as $\operatorname{lnCl})_{3}$ ). Electrodeposition time - $60 \mathrm{~min}$

Slika 4. Optička mikroskopska slika površine Pd-In prevlake elektrohemijski istaložene pri gustini struje $j=-0.3 \mathrm{~A} \mathrm{dm}^{2}$. Sastav elektrolita: $10 \mathrm{~g} \mathrm{dm}^{-3} \mathrm{NH}_{4} \mathrm{Cl}$, $10 \mathrm{~g} \mathrm{dm}^{-3}\left(\mathrm{NH}_{4}\right)_{2} \mathrm{SO}_{4}, 3 \mathrm{~g} \mathrm{dm}^{-3} \mathrm{Pd}$ (kao Palluna 460), $9 \mathrm{~g} \mathrm{dm}^{-3}$ In ( $\mathrm{kaO} \mathrm{InCl}_{3}$ ). Vreme taloženja

$$
-60 \min
$$

At lower cathodic current densities $(j<-0.2$ A $\mathrm{dm}^{-2}$ ) of electrodeposition, alloy surface is characterized by hills and valleys, as seen in Fig. 5 . The valleys of different shapes are completely surrounded by hills (a). Top surfaces of valleys and hills are practically the same, being characterized with cauliflower endings (b). 

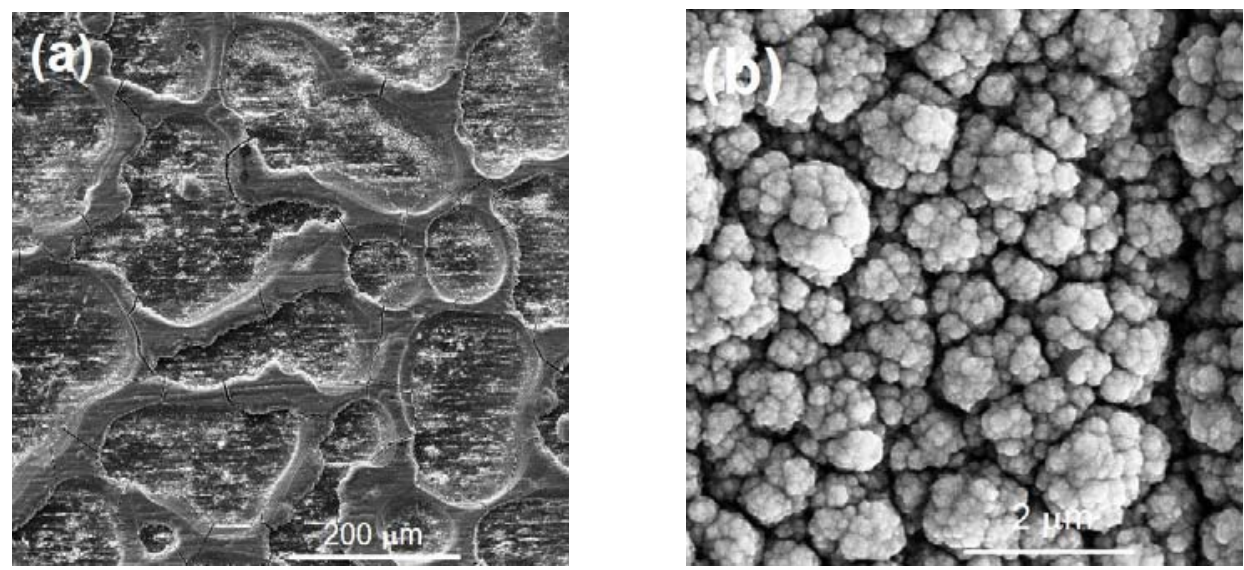

Figure 5. (a) SEM image of certain surface areas electrodeposited at lower cathodic current densities ( $j<$ $-0.2 \mathrm{~A} \mathrm{dm}^{-2}$ ). (b) Top surfaces of valleys and hills

Slika 5. (a) Skenirajuća elektronska mikroskopija određenih delova površine elektrohemijski istaložene pri manjim katodnim gustinama struje $\left(j<-0.2 \mathrm{~A} \mathrm{dm}^{-2}\right)$.

(b) Morfologija površine udubljenja i uzvišenja

The EDS line scan shows smooth distribution of both elements over the depth of the electrodeposit, indicating that self-organization occurs mainly at the alloy surface.

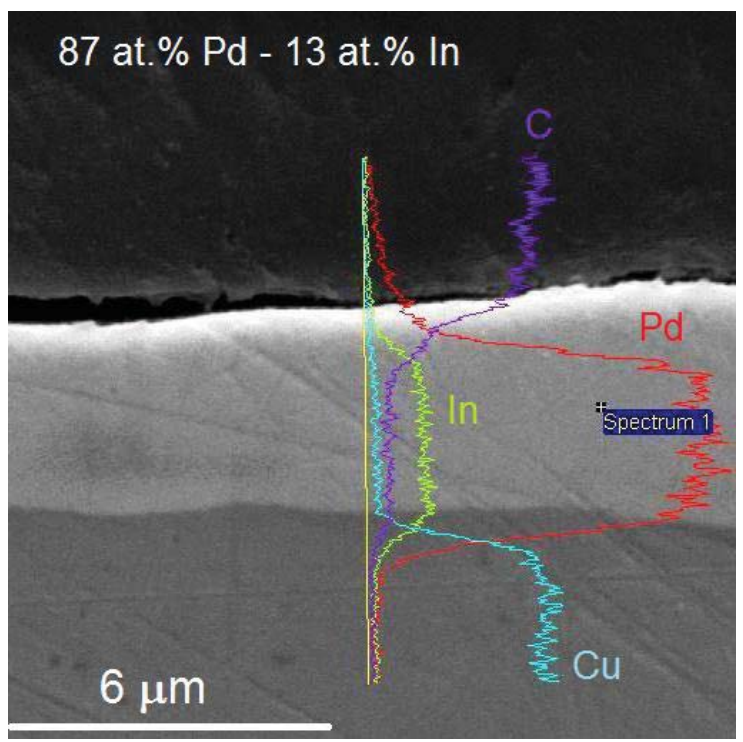

Figure 6. EDS line analysis of the cross-section of the $P d$-In coating

Slika 6. Linijska analiza energetski disperzivnom rentgenskom spektroskopijom poprečnog preseka prevlake Pd-In

\subsection{Indium-cobalt alloys}

The potentials of electrodeposition of Co and In metals are very close and the alloy coatings could be obtained mostly from the water solutions containing ions of both metals, without addition of any complexing agent [10].
The morphology of the formed structures, obtained during the electrodeposition of Co-In alloys has been used as a benchmark for the validation of the novel mathematical model for the formation of spatio-temporal patterns in electrodeposition, proposed by Bozzini et al. [11]. This model accounts for the coupling between surface morphology and surface composition important for the understanding the formation of morphological patterns found in electroplating.

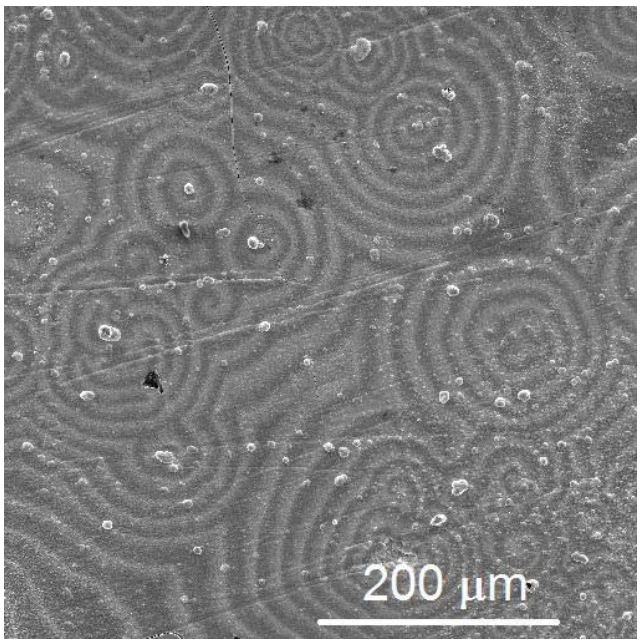

Figure 7. SEM image of Co-In coating electrodeposited at $j=-1 \mathrm{Adm} \mathrm{dr}^{-2}$ from the electrolyte containing $20 \mathrm{~g} \mathrm{dm}^{-3}$ di-ammonium hydrogen citrate, $30 \mathrm{~g} \mathrm{dm}^{-3} \mathrm{Co}\left(\right.$ as $\mathrm{CoSO}_{4} 7 \mathrm{H}_{2} \mathrm{O}$ ), $5 \mathrm{~g} \mathrm{dm}^{-3} \mathrm{In}$ (as $\mathrm{InCl}_{3}$ ). Electrodeposition time - $20 \mathrm{~min}$

Slika 7. Skenirajuća elektronska mikroskopija Co-In prevlake elektrohemijski istaložene pri gustini struje $j=-1 \mathrm{~A} \mathrm{dm}^{-2}$. Sastav elektrolita: $20 \mathrm{~g} \mathrm{dm}^{-3}$

$\left(\mathrm{NH}_{4}\right)_{2} \mathrm{HC}_{6} \mathrm{H}_{5} \mathrm{O}_{7}, 30 \mathrm{~g} \mathrm{dm} \mathrm{m}^{-3} \mathrm{Co}\left(\mathrm{kaO} \mathrm{CoSO}_{4} 7 \mathrm{H}_{2} \mathrm{O}\right), 5$ $\mathrm{g} \mathrm{dm}^{-3}$ In ( $\mathrm{kaO} \mathrm{InCl}_{3}$ ). Vreme taloženja - $20 \mathrm{~min}$ 
In the case of Co-In alloys the scale of the observed spirals is much lower than that observed for spatio-temporal structures formed on the surfaces of Ag-In and Pd-In alloy layers, as shown in Fig. 7. EDS analysis showed that the content of In is higher on top of the spirals in comparison with that between the spirals [5]. Hence, it appears that the formation of the spirals is the consequence of the electrodeposition of Co-In alloys with higher amount of In.

The cross-sections of Co-In coatings, taken at two positions of the coatings, are presented in Figs. 8 and 9.

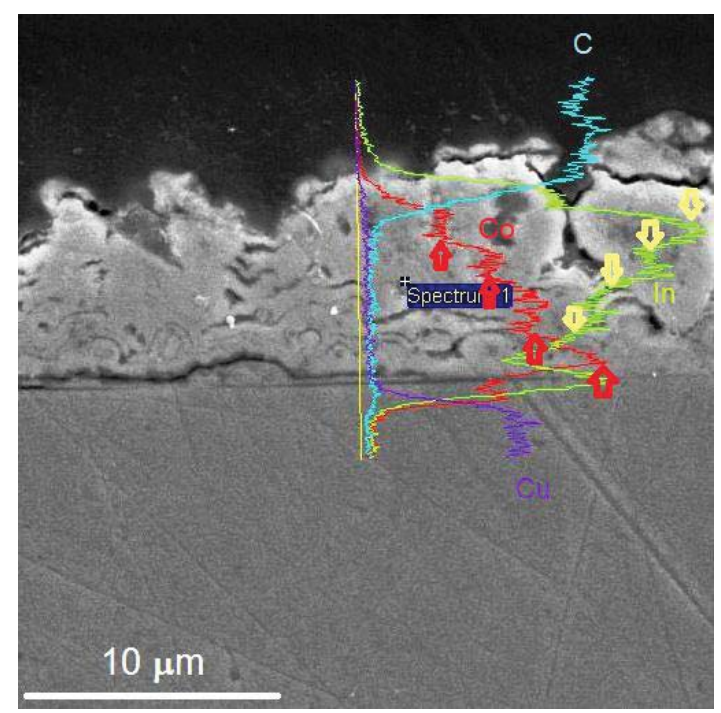

Figure 8. EDS linear analysis of the cross-section of Co-In coating

Slika 8. Linijska analiza energetski disperzivnom rentgenskom spektroskopijom poprečnog preseka prevlake Co-In

Considering Figs. 8 and 9 it could be concluded that in both figures exist certain layers with different compositions. In Fig. 8 four plateaus, or peaks, could be detected on the EDS line scan, as marked in the figure with arrows, while on this cross-section not well-defined leayered structure could be observed. Well-defined leayered structure is seen in Fig. 9, but it seems that such structure is not the consequence of the electrodeposition of thin layers with different compositions. It is most probable that the multilayers are the cosequence of the formation/destruction of a layer of passive indium hydroxide, due to alkalization in the vicinity of the electrote surface. As marked with the arrows in Fig. 9, three layers with different alloy compositions exist over the cross-section of Co-In alloy layer. Hence, for the Co-In alloy it could be stated that due to low scaling of spirals, their appearance could be the consequence of alloy layers containing different composition on the surface, as well as over the depth of the alloy coatings.

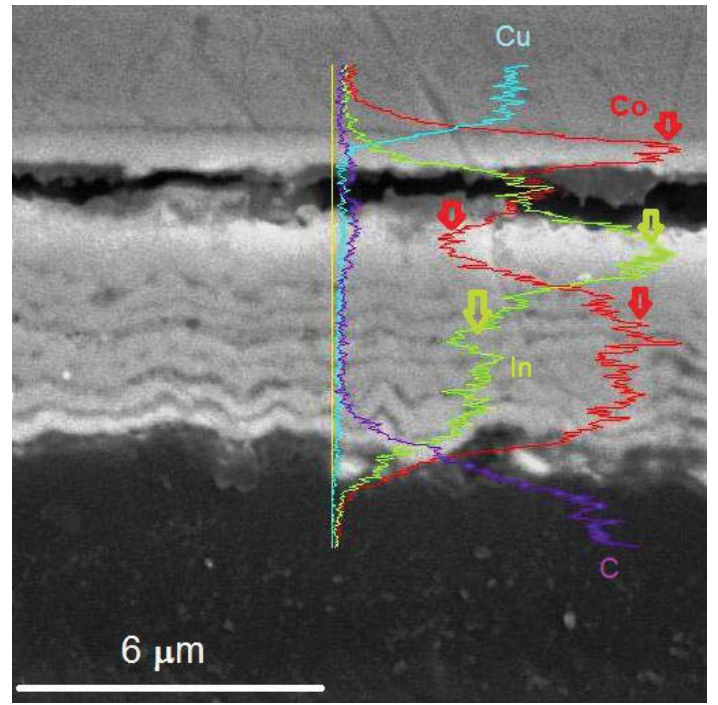

Figure 9. EDS linear analysis of the cross-section of Co-In coating

Slika 9. Linijska analiza energetski disperzivnom rentgenskom spektroskopijom poprečnog preseka prevlake Co-In

\section{CONCLUSIONS}

The appearance of spatio-temporal structures on the surface od electrodeposited alloy layers is characteristic for all three indium containing alloys. Well-distinguished spirals were detected only at the surfaces of Ag-In and Co-In alloys, while for Pd-In alloy spatio temporal structures are characterized with the valleys of different shapes surrounded by hills.

In the case of Ag-In and Pd-In alloy coatings the cross-section does not show the presence of alloy layers with different composition, due to the fact that spatio temporal structures are of large dimensions and cannot be seen on the high magnification images of the cross-sections.

EDS line scan of the cross-section of Co-In alloy layers indicates the presence of layers with different compositions at high magnification, confirming that spatio temporal structures are placed not only on the surface, but also in the bulk of the alloy coating.

\section{Acknowledgment}

This work was financially supported by the Ministry of Education, Science and Technological Development of the Republic of Serbia under the contract No. 172054. The authors would like to acknowledge the COST MP1407 action for STSM grant of Ts. Dobrovolska, reference No. COSTSTSM-MP1407-36010. 


\section{REFERENCES}

[1] Ts.Dobrovolska, I. Krastev (2010) Electrodeposition of silver-indium alloys, book Electrolysis: Theory, Types and Applications, Nova Science Publishers, p. 303-326.

[2] Ts.Dobrovolska, M.Georgiev, I.Krastev (2015) Electrodeposition of Indium and Indium Alloys, book Comprehensive Guide for Nanocoatings Technology, Nova Science Publishers.

[3] E.Raub, A.Schall, (1938) Silber-IndiumLegierungen, Zeitschr. Metallkunde, 30 (5), 149151.

[4] I.Krastev, T.Dobrovolska, R.Kowalik, A.Zielonka (2009) Properties of silver-indium alloys electrodeposited from cyanide electrolytes, Electrochim. Acta, 54, 2515-2521.

[5] T.Dobrovolska, L.Veleva, I.Krastev, A.Zielonka (2005) Composition and Structure of Silver-Indium Alloy Coatings Electrodeposited from Cyanide Electrolytes, J. Electrochem. Soc., 152 (3), C137C142.

[6] Y.N.Sadana, A.E.Keskinen, M.Guindon (1975) Electrodeposition and $\mathrm{x}$-ray structure of cobalt- indium alloys (initial studies), Electrodep. Surf. Treat., 3,149-157.

[7] S.Nineva, Ts. Dobrovolska, I.Krastev (2011) Zaštita Materijala, 52 (2), 80-84.

[8] Ts.Dobrovolska, V.D.Jovic, B.M.Jovic, I.Krastev (2007) Phase identification in electrodeposited AgIn alloys by ALSV technique, J. Electroanal. Chem., 611, 232-240.

[9] Ts.Dobrovolska, M.Georgiev, I.Krastev (2015) Electrodeposition of gold-indium Alloys, Trans. Inst. Met. Finish., 93 (6), 321-325.

[10] I.Krastev, T.Dobrovolska, U.Lacnjevac, S.Nineva (2012) Pattern formation during electrodeposition of indium-cobalt alloys, J. Solid State Electrochem., 16 (11), 3449-3456.

[11] B.Bozzini, M.Amati, L.Gregoratti, D. Lacitignola, I. Sgura, I.Krastev, T.Dobrovolska (2015) Intermetallics as key to spiral formation in In-Co electrodeposition. A study based on photoelectron microspectroscopy, mathematical modelling and numerical approximations, J. Phys. D, 48 (39), 395402.

\section{IZVOD}

\section{PROSTORNO-VREMENSKE STRUKTURE KOD ELEKTROHEMIJSKI ISTALOŽENIH LEGURA NA BAZI INDIJUMA}

Prevlake legura Ag-In, Pd-In i Co-In dobijene su elektrohemijskim taloženjem pri konstantnoj gustini struje iz različitih rastvora. Površinski izgled i sastav prevlaka su ispitivani skenirajućom elektronskom mikroskopijom (SEM) i energetski disperzivnom rentgenskom spektroskopijom (EDS).

Pojava prostorno-vremenskih struktura na površini elektrohemijski istaloženih prevlaka legura je karakteristična za sve ispitivane legure indijuma. Jasno definisane spiralne strukture su detektovane na površinama Ag-In i Co-In legura,dok su prostorno-vremenske strukture kod Pd-In legura okarakterisane pojavom udolina različitog oblika koje su okružene uzvišenjima.

$\mathrm{Na}$ poprečnom preseku legura Ag-In i Pd-In nije moguće detektovati slojeve sa različitim sastavom, jer su prostorno-vremenske strukture velikih dimenzija koje se ne mogu videti na slikama velike rezolucije (poprečni preseci). Linijska EDS analiza poprečnog preseka prevlake CoIn legure ukazuje na prisustvo slojeva različitih sastava (različite faze) i time potvrđuje prisustvo spirala ne samo na površini, već i po dubini taloga.

Ključne reči: prostorno-vremenske strukture, spirale, elektrohemijsko taloženje In legura, poprečni prsek taloga.

Naučni rad

Rad primljen: 05. 03. 2018.

Rad prihvacen: 24. 03. 2018.

Rad je dostupan na sajtu: www.idk.org.rs/casopis

(C) 2018 Authors. Published by Engineering Society for Corrosion. This article is an open access article distributed under the terms and conditions of the Creative Commons Attribution 4.0 International license (https://creativecommons.org/licenses/by/4.0/) 